\title{
K rozvoji interkulturní komunikační kompetence studentů učitelství anglického jazyka
}

\author{
Klára Kostková \\ Univerzita Karlova, Pedagogická fakulta, Katedra anglického jazyka a literatury
}

Redakci zasláno 21. 5. 2012 / upravená verze obdržena 8. 7. 2012 / k uveřejnění přijato 11. 7. 2012

\begin{abstract}
Abstrakt: Cílem studie je představit výzkumné šetření v oblasti hodnocení rozvoje interkulturní komunikační kompetence (dále ICC $^{1}$ ) u studentů učitelství anglického jazyka pro základní školy v rámci studijního předmětu Intercultural Communicative Competence. Fenomén interkulturality klade nové nároky nejen na pedagogickou praxi, ale i výzkum. Zaměřujeme se tedy na tematiku interkulturní výchovy a vzdělávání s klíčovým cílem rozvoje ICC. Předpokladem pro výzkumné uchopení problematiky je konceptualizace konstruktu ICC a jeho následná didaktizace, tj. rozvoj a hodnocení. V rámci realizovaného výzkumného šetřeníjsmevyužili kvantitativníhoi kvalitativního př́stupu ke sběru i analýze dat; jako techniky sběru dat byl využit dotazník YOGA Form a ohniskové skupiny, jejichž transkripty byly podrobeny obsahové analýze. Výzkumný soubor tvořilo 17 studentů učitelství anglického jazyka (15 žen a 2 muži; průměrný věk: 24 let). Cílem výzkumného šetření bylo odhalit, zda u studentů na základě absolvování studijního předmětu Intercultural Communicative Competence došlo k rozvoji jednotlivých dimenzí ICC a pokud ano, tak jakých dimenzí a v jaké míře. Výsledky výzkumu potvrdily, že u studentů došlo k rozvoji všech dimenzí ICC, avšak v různé míře. Signifikantní rozvoj byl zaznamenán v oblasti dimenzí znalostí a dovedností. V rámci dimenze povědomí a postojové pak došlo $\mathrm{k}$ iniciaci rozvojových tendencí, což s ohledem na obtížnost jejich didaktizace hodnotíme kladně, jelikož i podpora rozvoje reflektivního potenciálu studentů ve vztahu k rozvoji ICC (i iniciaci toho rozvoje) hraje důležitou roli. Na základě výsledků výzkumu diskutujeme možné implikace těchto výstupů, tj. zejména rozvoj dimenze znalostní a dovednostní, pro teorii i praxi.
\end{abstract}

Klíčová slova: interkulturní komunikační kompetence (ICC), rozvoj interkulturní komunikační kompetence, hodnocení interkulturní komunikační kompetence, YOGA Form

1 S ohledem na kontext výzkumu, tj. anglický jazyk, i s ohledem na celosvětově uznávaný úzus přistupujeme i v rámci českého prostředí k užívání zkratky ICC (oproti IKK). 
Motto: Světem obchází strašidlo - strašidlo globalizace. Tato nepríliš pưvabná dáma zdá se dokonce krapáček démonická. S jejím príchodem tudíž vzniká otázka, zda má démona dobrého,

či zlého. Ale jak na takovou otázku může odpovědět vědec, je-li nucen oficiálně sdílet mýtus o oddělení poznání a hodnot? (Kot’a, 2000)

\section{1 Úvodem}

Úvodní motto metaforicky zrcadlí svět, ve kterém žijeme a formuluje zásadní výzvu pro vědu a výzkum, kterou tento svět reprezentuje. Přestože má setkávání se a prolínání kultur světa dlouhou a bohatou historii, multikulturalismus zůstává výzvou pro oblast vzdělávání, resp. pro výchovně-vzdělávací potřeby s ním spojené. Faltýn charakterizuje multikulturalismus jako „možnost, jak bez předsudků a zároveň bez iluzí sdílet komunikační prostor bez ohledu na lidskou příslušnost ke skupinám“ (2005, s. 18). S využítím „advanced organizer" pro perspektivu, kterou tento text zastává, lze jednoduše říci, že multikulturní svět tudíž nemůže existovat bez interkulturní komunikační kompetence (Intercultural Communicative ${ }^{2}$ Competence, dále ICC) jeho populace. Fantini předkládá jednoduchou definici ICC jako schopnosti fungovat efektivně a vhodně v interakci s členy odlišných kulturních skupin $(2001$, s. 2). $\mathrm{K}$ takovéto interakci je mnohdy nutností vybavenost $\mathrm{v}$ jiném než mateřském jazyce, a to nejen z hlediska znalosti systému jazyka, ale i v rámci schopnosti tento jazyk vhodně používat s ohledem na sociální kontext. Schopnost užívat jazyk v komunikaci mezi kulturami vhodně a efektivně, tj. komunikovat interkulturně kompetentně, tedy zahrnuje ještě více, a to ohled na různá kulturní specifika jedinců i sociálních skupin. Všechno toto se přirozeně zrcadlí i v problematice výchovně-vzdělávacího procesu.

Chceme-li alespoň částečně reflektovat a hlouběji poznat potřebu začlenění interkulturní výchovy a vzdělávání (dále IVV) do výchovně-vzdělávacího procesu, předpokládá to vymezení relevantních teoretických východisek, především konceptualizaci konstruktu ICC i jeho didaktizaci, tj. rozvoj a hodnocení v kontextu výuky anglického jazyka. Vzhledem k tomu, že relativně

\footnotetext{
Překlad anglického termínu communicative competence do českého jazyka je nejednotný: častěji se objevuje termín komunikativní kompetence (a to i ve Společném evropském referenčním rámci pro jazyky, 2002; dále též Ježková, 2003; Mareš \& Gavora, 1999). Bohemisté (např. Hrdlička, 2005) však upozornili, že je vhodnější užívat přídavné jméno komunikační, odvozené od podstatného jména komunikace, spíše než přídavné jméno komunikativní, odvozené od podstatného jména komunikativnost.
} 
nedávno definovaná problematika IVV klade nové nároky (především) na učitele, klíčové aktéry vzdělávacího procesu, zaměřujeme se na studenty učitelství. S ohledem na tento kontext je cílem našeho výzkumu hodnocení rozvoje ICC u studentů učitelství anglického jazyka. Zaměřujeme se tedy na budoucí učitele anglického jazyka, aby se ve své budoucí pedagogické praxi sami mohli stát úspěšnými zprostředkovateli ICC pro své žáky. V závěru diskutujeme možné implikace výsledků našeho výzkumu pro pedagogickou praxi i další výzkum. Jsme si však vědomi Dayova $(2011$, s. 26) upozornění, že propast mezi pedagogickým výzkumem a praxí je komplexnější fenomén, než je běžně předpokládáno v odborné literatuře.

\section{Teoretická východiska: základní terminologie a stav poznání}

První vlaštovky věnované této problematice (tj. problematice IVV, at' už koncepčně, či terminologicky různě pojaté) se v kontextu České republiky objevily teprve počátkem 90 . let 20 . století. Přestože se jedná o více než dvě dekády a IVV (opět v různých terminologických pojetích) již zakotvila i v českých kurikulárních dokumentech (např. Bílá kniha, rámcové vzdělávací programy - RVP), je stále oblastí terminologicky i koncepčně neujasněnou a cíle, obsahy a procesy jejího rozvoje i podmínky implementace jsou zastřeny jistou pluriformitou myšlenek ${ }^{3}$. Shrneme-li cíl IVV, na kterém se shodují mnohé odborné zdroje, lze jej definovat jako rozvoj ICC, která se skládá z různých dílčích složek, resp. dimenzí (Byram, 1997; Deardorff, 2009; Janebová \& Kasíková, 2007 aj.).

Zároveň si však uvědomujeme upozornění autorů, např. Leemanové a Ledouxové (2005, s. 575), dle kterých je teoretická debata o IVV odtržena od každodenní praxe ve třídě, resp. že praktický záměr IVV a vývoj teorie IVV se bohužel ubírají různými směry. Lze navíc dodat, že IVV ani její výzkum nejsou dostatečně zaměřeny na výuku cizích jazyků, přičemž právě ta je vnímána jako jeden $\mathrm{z}$ nejdůležitějších prostředků vedoucích k rozvoji ICC a tím k úspěšné interkulturní komunikaci. Neopomenutelnou otázkou pak je rozpracování IVV s cílem rozvoje ICC v kurikulárních dokumentech konkrétních

3 Jsme si vědomi faktu, že tato pluriformita myšlenek může být zapř́činěna multiparadigmatickým přístupem či nedostatečnou konceptualizací diskutované problematiky, což dále ovlivňuje užívanou terminologii. 
škol, tj. ve školních vzdělávacích programech ${ }^{4}$ (ŠVP; srov. Kostková, 2012a), a praktická aplikace IVV v realitě školních tříd.

\subsection{Interkulturní komunikační kompetence: konceptualizace, rozvoj a hodnocení}

Ačkoli teoretická východiska i praxe rozvoje ICC $^{5}$ prošly značným vývojem, mnozí autoři (Deardorff, 2009; Fantini, 2000; Leeman \& Ledoux, 2005; Průcha, 2001, 2010 aj.) se stále shodují na jistých kritických aspektech a výzvách pro teorii, výzkum i praxi v této oblasti. Patř́ k nim: (a) nejednotné konceptuální uchopení, (b) omezená výzkumná šetření, (c) propast mezi teorií a praxí a (d) nedostatečně propracovaný systém hodnocení. Pro potřeby realizovaného výzkumu se proto zaměřujeme zejména na definici a konceptualizaci ICC, dále pak věnujeme pozornost jejímu rozvoji a hodnocení.

Obecné definice ICC se v mnohém shodují, např. Deardorffová $(2009$, s. xi) definuje ICC jako vhodnou a efektivní komunikaci a chování v interkulturních situacích, a to na základě postojů, interkulturních znalostí, dovedností a reflexe. Obdobně vymezuje Fantini ICC jako schopnost komunikovat efektivně a vhodně s lidmi z jiných lingvistických a kulturních prostředí. Navíc pak ale dodává, že komunikovat efektivně reflektuje pohled mluvčího na vlastní projev v cílovém jazyce (pohled zvnějšku, tzv. etic pohled); komu-

Autorka textu realizovala výzkum v oblasti rozpracování cílů IVV v českých kurikulárních dokumentech, konkrétně v ŠVP 37 základních škol. Akcent byl kladen na pojetí ICC v rámci vzdělávací oblasti Jazyk a jazyková komunikace, obor Cizí jazyk a v rámci průřezového tématu Multikulturní výchova. Pro tyto účely byla zvolena metoda obsahové analýzy, která je vhodná $\mathrm{k}$ analýze produktů, obsahové analýze byly podrobeny očekávané výstupy $\mathrm{v}$ dané vzdělávací oblasti, výsledky zdaleka nelze označit za uspokojivé, jelikož z celkového počtu 3182 očekávaných výstupů bylo pouze 199 (tj. 6 \%) interkulturně zaměřených (podrobněji Kostková, 2012a).

5 V současném pojetí existuje jistý významový rozdíl mezi termíny interkulturní kompetence a interkulturní komunikační kompetence. Interkulturně kompetentní jedinec je schopen komunikovat $\mathrm{s}$ jedinci $\mathrm{z}$ jiných zemí a kultur ve svém mateřském jazyce; během této komunikace čerpá ze znalostí o interkulturní komunikaci, postojích, dovednostech, z předešlé zkušenosti atd.; mnohé z těchto definic pocházejí z provenience anglicky mluvících zemí (např. Fantini, 2001). Oproti tomu ICC umožňuje navíc komunikovat s lidmi z jiných zemí a kultur v jazyce cizím; znalosti o cizí kultuře, jejích hodnotách, zvyklostech atd. jsou spojeny s jejich cizojazyčnou komunikační kompetencí, a to skrze schopnost užívat cizí jazyk vhodně (sociolingvistická a diskursivní kompetence, např. Byram, 1997, s. 71) i skrze povědomí o specifických významech, funkcích a konotacích cizího jazyka, tj. jazyka užívaného k interkulturní komunikaci. S ohledem na kontext naší práce a studium teoretických zdrojů se pak přikláníme k termínu ICC. 
nikovat vhodně pak reflektuje, jak rodilí mluvčí cizího jazyka vnímají tuto

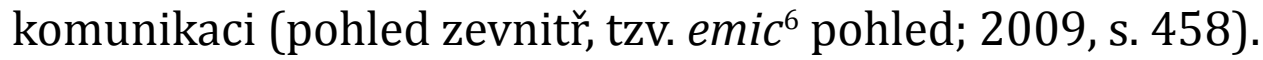

Stejně jako definic existuje i řada modelů ICC a jejich typologií (podrobněji viz Spitzberg \& Changnon, 2009, s. 7-34; Kostková, 2012b). Autoři většinou sdílejí názor, že ICC je gestalt, v němž lze pouze identifikovat dílčí a vzájemně komplementární složky ${ }^{7}$. Jejich počet se liší dle zvoleného přístupu. Jelikož existuje celá řada cenných modelů i definic, není možno tuto širokou problematiku obsáhnout jejich úplným výčtem a popisem, proto zde přijímáme jako výchozí relativně jednoduchý, ale současně velice komplexní model ICC vlivného amerického interkulturalisty A. Fantiniho, a to návrh konstruktu ICC (A Construct Proposal) a jejích složek. Dle Fantiniho jsou komponenty (components) ICC následující: (a) šíře (variety) rysů/znaků/ vlastností/charakteristik, např. respekt, empatie, víra, flexibilita, zvídavost, otevřenost, smysl pro humor; (b) tři oblasti/domény (areas or domains): schopnost navázat a udržet vztahy, schopnost komunikovat s minimální ztrátou obsahu či zkreslením, schopnost spolupracovat za účelem uskutečnění něčeho oboustranně potřebného či zajímavého; (c) čtyři dimenze: znalosti (knowledge), (pozitivní) postoje (/positive/ attitudes), dovednosti (skills) a povědomí (awareness); (d) způsobilost v cizím jazyce (proficiency in the host language) a (e) různé úrovně dlouhodobého a vývojového procesu: proces rozvoje je možno strukturovat do tzv. ukazatelů8 ${ }^{8}$ rozvoje ICC. Fantini je dělí na čtyři základní úrovně: úroveň I: vzdělávající se cestovatel, úroveň II: sojourner (pobývající), úroveň III: profesionál, úroveň IV: interkulturní/ multikulturní specialista (1995; revidovaný 2001). Mnohé další dostupné modely (např. Byram, 1997; Byram \& Fleming, 1998; Deardorff, 2004) pak pracují pouze se složkami dimenzí (složka c) a komunikační kompetence v cizím jazyce (složka d). Tyto dvě složky chápeme jako stěžejní, jelikož je hodnotíme jako vhodné pro následnou operacionalizaci pro každodenní praxi ve třídě na straně jedné (tj. didaktizace modelu ICC) i jako potenciální výzkumné proměnné na straně druhé (tj. užitý kategoriální systém).

Termíny emic a etic (představeny lingvistou Pikem) popisují dva různé druhy chování: emic zahrnuje chování a víru jedinců uvnitř kultury, je tedy závislé na kontextu dané kultury; etic hledá společné, resp. popisuje totožné chování aplikovatelné na ostatní kultury (bez kulturních, jazykových aj. specifik) - snaží se být neutrální (volně např. Fantini, 2009, s. 458).

7 Podrobněji o modelování kompetencí, např. Klieme et al. (2010). K modelům v pojetí multikulturní kompetence / multikulturních kompetencí též Hladík (2010) či Zerzová (2012).

8 Obdobné dělení lze nalézt např. v SERRJ (2002, s. 23). 
V kvantitě i kvalitě dimenzí vymezujících ICC se však autoři liší. Provedli jsme proto analýzu vybraných 17 modelů ICC s cílem ověřit tuto složku Fantiniho návrhu modelu ICC ( $\mathrm{tj}$. složku c), konkrétně tedy vymezit dimenze ICC, jelikož zejména ty tvoří obsah i cíle IVV ${ }^{9}$. Provedená analýza (podrobněji viz Kostková, 2010) postihla fenomén interkulturality $\mathrm{z}$ perspektivy komplexnější než jednotlivé výše prezentované pohledy, odhalila však mnohé společné složky konstruktu ICC. Na tomto místě představujeme výsledky na úrovni dimenzí tvořících model ICC, který přijímáme jako výchozí: dimenze povědomí, postojů, dovedností a znalostí1 ${ }^{10}$; dimenze povědomí je chápána jako dimenze centrální (podrobněji Kostková, 2010, 2012b). Komunikační kompetence v cizím jazyce ${ }^{11}$ pak tvoří další zásadní dimenzi ICC, ve které jsou ostatní čtyři dimenze zakotveny.

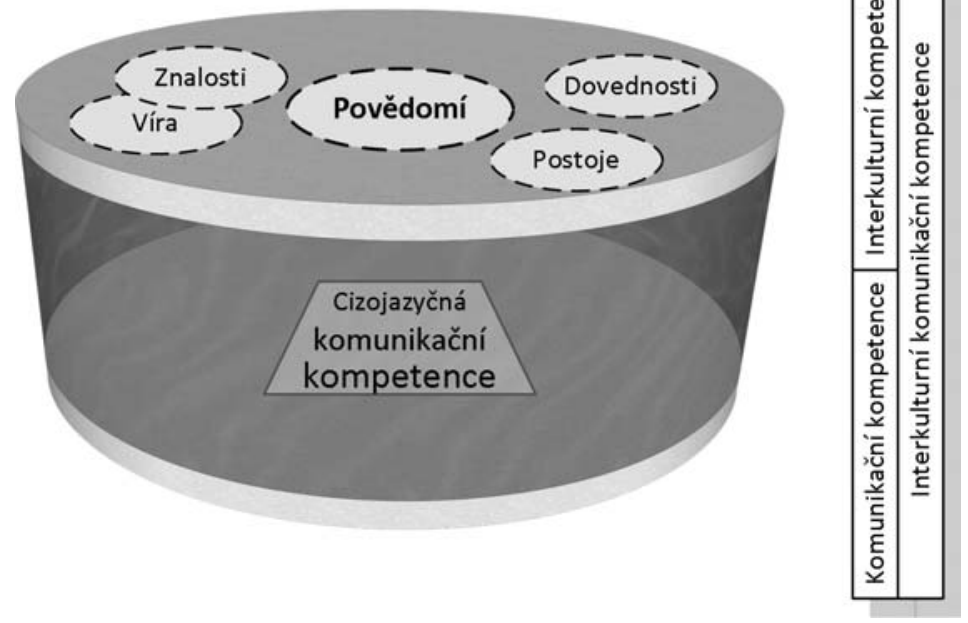

Obrázek 1. Model dimenzí ICC (Kostková, 2012b).

Po vymezení modelu ICC zde ovšem přetrvává potřeba operacionalizace tohoto konstruktu, a to zejména s ohledem na rozvoj a hodnocení.

9 Dále pak výsledné dimenze slouží jako kategoriální systém obsahových analýz realizovaných v empirické části práce.

10 V souvislosti se znalostní dimenzí považujeme za nutné upozornit na úzkou provázanost této dimenze s vírou (belief). „Víra je myšlenka o světě, o které lidé předpokládají, že je pravdivá. Víra je tedy soubor naučených interpretací, na základě kterých se př́íslušníci kultur rozhodují o tom, co je a není logické a správné" (Lustig \& Koester, 2006, s. 87).

11 Konstrukt komunikační kompetence prošel dlouhodobým vývojem (Hymes, 1972; Canale \& Swain, 1980; Bachman, 1990 aj.), s ohledem na ICC je však vhodné poukázat na model komunikační kompetence integrující řečové dovednosti a interkulturní kompetenci (UsóJuan \& Martínez-Flor, 2006; česky Šebestová, 2011). 
Pozornost věnovaná odborníky rozvoji ICC i množství zdrojů, které mohou inspirovat učitele při plánování a realizaci výuky, vzrůstá (např. Tomalin \& Stempleski, 1993; Byram, Nichols, \& Stevens, 2001; projekt Varianty, 2002), přesto je ale patrné, že potřeba konkrétně didakticky uchopit model ICC přetrvává. Tento fakt považujeme za logický, jelikož je rozvoj ICC v kontextu formálního vzdělávání většinou integrován do vyučovacích předmětů. Různé vzdělávací obory s sebou přinášejí i vlastní přístupy a metody výuky, které se vyvíjejí v jednotlivých oborových didaktikách. Možnost volit vhodné přístupy a metody z nabídky, která je $\mathrm{k}$ dispozici, je - v kontextu výuky anglickému jazyku - v plném souladu se současně dominantním eklektickým modelem, který je znakem tzv. post-method era (podrobněji např. Richards \& Rodgers, 2001).

Pro potřeby rozvoje ICC vnímáme jako vhodné přístupy zkušenostního a kooperativního učení. Jako př́nosnou chápeme rovněž posloupnost rozvoje jednotlivých dimenzí ICC v souladu s Abramovým ABCD Crow př́ístupem. „Jedná se o relativně nový model pro interkulturní výchovu a vzdělávání" (Abram, 2001, s. 1), který představuje obecnou klasifikaci (a souslednost) praktických aktivit rozvíjejících ICC ve sledu: A - autobiografie (authobiography, i.e. identity, self-image), B - biografie (biography, i.e. imago, the picture that others form of you), C - konflikt (conflict), D - dialog (dialogue). Tenze mezi autobiografií a biografií je pak vyhrocena bud' pozitivně - jako dialog, nebo negativně - jako konflikt (podrobněji např. Abram, 2001). Jako centrální př́ijímáme rozvoj dimenze povědomí (sebe sama, vlastní kultury a následně ostatních), které by měla být věnována pozornost v počátku procesu rozvoje ICC. Jsme si rovněž vědomi faktu, že se procesy rozvoje jednotlivých dimenzí liší, zahrnují jednak relativně novou a komplikovanou problematiku rozvoje dimenzí povědomí a postojů, a oproti tomu snadněji ovlivnitelné a didakticky uchopitelné dimenze znalostí a dovedností.

Rozvoj ICC je nutné rovněž podrobit procesu hodnocení, což před nás klade otázku: Jak ICC hodnotit? K jejímu zodpovězení zvažujeme řadu aspektů souvisejících s hodnocením ICC i jejich vzájemné vztahy ${ }^{12}$. Jsme si vědomi faktu, že je hodnocení dosažené úrovně ICC pro vzdělavatele i výzkumníky výzvou.

12 Tj. hodnocení přímé a nepřímé; hodnocení performance a kompetence; hodnocení pozorovatelného a nepozorovatelného, tj. tacitního; hodnocení analytické a holistické; hodnocení kvalitativní a kvantitativní, příp. smíšené; hodnocení sumativní a formativní; hodnocení formální a neformální; sebehodnocení, hodnocení spolužáky, učitelem, standardizované hodnocení externí autoritou; hodnocení komerční a hodnocení nekomerční. 
Především je problematické obsáhnout ICC v její komplexnosti, ozývají se i hlasy ohledně oprávněnosti jejího hodnocení. Tyto obavy vnímáme jako opodstatněné, zastáváme však názor, že by v souvislosti s tzv. backwash efektem mělo mít hodnocení ICC své pevné místo v procesech vyučování a učení se. Je však nutné k němu přistupovat citlivě, částečně i proto považujeme za stěžejní roli sebehodnocení. Externí hodnocení může mít na učící se jedince značný vliv, natož u tak citlivých aspektů jejich osobnosti jako jsou např. postoje a povědomí, které mají hluboké kořeny v rodině, společnosti a kultuře.

\section{Výzkumné šetření: hodnocení rozvoje ICC}

Výzkumné šetření je věnováno výzkumu v oblasti hodnocení rozvoje ICC v kontextu formálního vzdělávání, specificky je výzkum zaměřený na rozvoj ICC u studentů učitelství anglického jazyka v průběhu studijního předmětu Intercultural Communicative Competence ${ }^{13}$.

Výzkum si kladl za cíl zodpovědět následující otázky:

1. Došlo v průběhu studijního předmětu Intercultural Communicative Competence u studentů k rozvoji ICC, respektive jejích dimenzí?

2. Pokud ano, k rozvoji kterých dimenzí došlo a v jaké míře?

Uvedené výzkumné otázky jsme se pokusili zodpovědět jednak v rovině horizontální (tj. šíŕi chápání konstruktu ICC studenty, tj. jak komplexně problematiku ICC vidí), dále pak v rovině vertikální (tj. hloubku porozumění jednotlivým dimenzím ICC studenty).

\subsection{Metodologie výzkumu}

V rámci realizovaného výzkumného šetření jsme využili kvantitativního i kvalitativního přístupu ke sběru i analýze dat. Výzkumný soubor tvořilo 17 studentů (15 žen a 2 muži; průměrný věk: 24 let) v rámci konkrétního studijního předmětu realizovaného v letním semestru 2008/2009.

Techniky sběru dat

Pro potřeby sběru dat jsme přistoupili ke kombinaci dvou metod s cílem dodržet principy triangulace, a to triangulaci v kombinaci kvalitativní a kvan-

13 Název studijního předmětu uvádíme v anglickém jazyce, jelikož je v tomto jazyce realizován (stejně tak jako otázky využité v rámci ohniskových skupin a ukázky položek z dotazníku YOGA Form, viz níže). 
titativní metodologie, $v$ kombinaci dvou technik sběru dat i v kombinaci dvou nezávislých výzkumníků (kódovatelů). Z možného výběru vhodných technik a nástrojů hodnocení rozvoje ICC (podrobný výčet viz Kostková, 2012b) volíme s ohledem na vysokou míru individualizace ohniskové skupiny a dotazník YOGA Form (Fantini, 2005; podrobněji též Kostková, 2012b). Vedeni cílem získat odpovědi na výzkumné otázky (tj. hodnocení rozvoje ICC) proběhl sběr dat ve dvou fázích (tj. vstupní a výstupní). Obě fáze byly zaměřeny na dosaženou úroveň ICC studentů, a to $\mathrm{v}$ počátku semestru a následně $\mathrm{v}$ jeho závěru:

1. vstupní fáze: ohniskové skupiny, dotazníkové šetření - YOGA Form,

2. výstupní fáze: ohniskové skupiny, dotazníkové šetření - YOGA Form.

S ohledem na principy realizace ohniskových skupin bylo nutné skupinu studentů (17) rozdělit. Celkem byly tedy realizovány čtyři ohniskové skupiny, z toho dvě na začátku $(9+8$ studentů $)$ a dvě na konci $(9+8$ studentů) studijního předmětu Intercultural Communicative Competence. I proto jsme přistoupili ke standardizovanému přístupu formou kladení identických otázek. Jako nejvhodnější jsme zvolili tzv. polostrukturovanou ohniskovou skupinu, která předpokládá přípravu okruhů modelových otázek, jejichž pořadí však není pro moderátora závazné, záleží spíše na průběhu skupiny a vývoji situace. $\mathrm{V}$ počátku semestru zahrnovaly polostrukturované ohniskové skupiny tři základní tematické okruhy, a to: co si studenti pod pojmem ICC představují, jaká mají od daného studijního předmětu očekávání a co s sebou do procesů rozvoje ICC přinášeji ${ }^{14}$, resp. čím mohou přispět. Jak je patrné z otázek, které moderátor $\mathrm{v}$ rámci ohniskové skupiny kladl, cílily na představy a chápání ICC samotnými studenty, tzn. moderátor sám nekladl otázky týkající se jednotlivých dimenzí ani dimenze nepojmenoval (obdobná strategie byla využita i při realizaci ohniskových skupin v závěru semestru.). Konkrétní otázky kladené v průběhu ohniskových skupin byly následující: What do you imagine under the term ICC? $\rightarrow$ Why did you sign for this course + what are your expectations? $\rightarrow$ What are you bringing into this course? What did you pack into your luggage? $\rightarrow$ Anything anyone would like to add at the end?

Polostrukturované ohniskové skupiny realizované $\mathrm{v}$ závěru studijního předmětu zaměřeného na rozvoj ICC studentů zahrnovaly opět tři základní

14 Odpovědi na tuto otázku jsou (stejně jako vnásledující výstupní fázi) elicitovány tzv. „zabalením si vlastního zavazadla“ (podrobněji Kostková, 2012b). 
tematické okruhy, a to: co je dle studentů ICC, s čím opouštějí daný studijní předmět a zda byla očekávání od daného studijního předmětu naplněna. Otázky této ohniskové skupiny měly za cíl elicitovat takové odpovědi, aby byly výstupy porovnatelné s odpověd'mi získanými z ohniskových skupin $\mathrm{v}$ počátku semestru. Otázky kladené $\mathrm{v}$ prủběhu ohniskových skupin byly následující: What is, in your opinion, ICC? (your interpretation of ICC?) $\rightarrow$ What are you leaving this course with? What did you pack into your luggage? $\rightarrow$ Were your expectations fulfilled? If yes - in what way? If not - why not?

Hlavní technikou využitou $\mathrm{k}$ analýze dat získaných $\mathrm{z}$ realizovaných ohniskových skupin byla obsahová analýza. Univerzum bylo v našem případě rámcováno výstupy ohniskových skupin, tj. videozáznamy a jejich transkripcí. Výběr a definování kategorií (např. Holsti, in Janoušek, 2007, s. 117-118) obsahové analýzy bylo řízeno teorií, jednotlivé dimenze ICC tedy tvořily kategorie pro realizovanou analýzu. Kloníme se tímto k názoru Miovského, že vytváření analytických kategorií ${ }^{15}$ vychází z proměnných a cílů výzkumu (2006, s. 240), v našem př́ípadě byl kategoriální systém definován na základě teoretického vymezení konstruktu ICC, tj. dimenze (kategorie): povědomí, postojů, znalostí a dovedností, které jsou zakotveny v kontextu cizojazyčné komunikační kompetence. Cílem obsahových analýz záznamů z ohniskových skupin bylo získat data kvalitativního charakteru vypovídající o míře porozumění ICC a jejím jednotlivým dimenzím studenty, resp. pak s ohledem na výzkumné otázky zaznamenat případný posun tohoto porozumění.

Dotazníkové šetření standardizovaným dotazníkem YOGA Form jsme využili jako komplement ohniskových skupin. Přikláníme se tak např. k akcentaci formativního hodnocení, užívání individuální vztahové normy a sebehodnocení (YOGA Form). Dotazník YOGA Form jsme vyhodnotili jako nejvhodnější pro potřeby hodnocení rozvoje ICC v pojetí, jak jsme ICC vydefinovali na základě provedené analýzy vybraných modelů. Zvolený dotazník svým zaměřením na dimenze povědomí, postojů, znalostí a dovedností odpovídá našemu modelu ICC (viz obr. 1; je rovněž základem pro plánování cílů i obsahu konkrétního studijního předmětu). Jedná se o nástroj americké provenience, který byl se svolením garanta autorského týmu, A. Fantiniho z University of Vermont, nově přenesen do českého kontextu. Dotazník byl následně drobně modifikován pro studenty (učitelství) anglického jazyka v prostředí

15 Jelikož mohou být kategorie různorodé, využili jsme v souladu s Janouškem (2007, s. 117) dělení analytických kategorií na substanciální (tj. co se říká) a způsobové (tj. jak se to říká). 
české vysoké školy, a to v části zabývající se reflexí vlastní kultury a kultury cílového jazyka ${ }^{16}$. Cílem dotazníkového šetření YOGA Form z hlediska výzkumného bylo zjištování dosažené úrovně ICC u respondentů v počátku a závěru semestru, porovnáním těchto výsledků pak hodnocení rozvoje ICC v oblastech čtyř jejích dimenzí. Z hlediska vzdělávacích cílů byla cílem podpora reflexe a sebereflexe $\mathrm{v}$ oblasti osobnostních a kulturních charakteristik a v oblasti cizojazyčné komunikační kompetence. Oblasti sledované dotazníkem tak reflektují teoretická východiska, tj. jednotlivé složky konstruktu ICC. Dotazník tedy naplňoval kritéria obsahové validity, tj. míru, do jaké je obsah výzkumného nástroje v souladu s obsahem zjištované oblasti (podrobněji Gavora, 2010, s. 86). Pro potřeby našeho výzkumu využíváme čtyři baterie otázek čítající v souhrnu 54 uzavřených položek s šestiúrovňovou Likertovou škálou (0 až 5) vyjadřující míru souhlasu (max. 5), resp. nesouhlasu (max. 0) $\mathrm{s}$ jednotlivými výroky prostřednictvím sebereflexe studentů. Oblastí zájmu čtyř baterií v této části dotazníku byly jednotlivé dimenze ICC; uved'me zde ukázky položek ze dvou dimenzí.

Znalosti:

7. I can cite important historical and socio-political factors that shape my own culture and the target culture $\quad \square 0 \square 1 \square 2 \square 3 \square 4 \square 5$

Dovednosti:

26. I believe I could adjust my behaviour, dress, etc. as appropriate, to avoid offending the target culture members

\subsection{Výsledky výzkumu}

Vzhledem $\mathrm{k}$ charakteru výzkumu nebyla analýza dat strukturována dle vstupní a výstupní fáze, ale dle technik sběru dat, a to s ohledem na reálný časový harmonogram sběru dat, tzn. nejprve ohniskové skupiny a následně dotazníkové šetření. Pozornost byla tedy nejprve věnována kvantitativní a nosnější kvalitativní analýze dat získaných v rámci obsahových analýz záznamů z ohniskových skupin. Poté jsme se zaměřili na kvantitativní analýzu dat získaných z dotazníkového šetření YOGA Form. V obou případech bylo cílem hodnotit rozvoj jednotlivých dimenzí ICC studentů v průběhu daného studijního předmětu, a zodpovědět tak předložené výzkumné otázky.

16 Modifikovaná verze YOGA Form prošla externí oponenturou v osobě autora její originální verze Fantiniho (podrobněji Kostková, 2012b). 
Jsme si vědomi limitů, které s sebou přinášejí různé metody výzkumu, resp. techniky sběru dat, a jejich možného vlivu na získaná data. Je proto nutné se tázat, zda a do jaké míry naše výsledky odpovídají realitě. Možný vliv metody ohniskových skupin na výsledky této fáze výzkumného šetření proto vidíme zejména $\mathrm{v}$ sebestylizaci studentů $\mathrm{v}$ rámci komunikace tváří $\mathrm{v}$ tvář za přítomnosti vyučujícího, resp. hodnotitele. Lze se tedy domnívat, že výroky studentů mohly být ovlivněny usuzováním, jaké typy opovědí byly $\mathrm{v}$ daném kontextu žádoucí, tzn. že akcent na konkrétní dimenze vyjadřovaný v průběhu studijního předmětu vyučujícím mohl mít (přímý i nepřímý) vliv na kvalitu studentských výpovědí. Dále pak je nutné uvažovat o dynamice skupinové interakce $\mathrm{v}$ rámci ohniskových skupin. Přestože jsme zvolili formát polostrukturované ohniskové skupiny, jsme si vědomi faktu, že může být interakce ve skupině velmi dynamická a poskytovat tak možnost $\mathrm{k}$ řízení a směřování diskuse $\mathrm{k}$ různým tématům, $\mathrm{v}$ našem případě např. dimenzím, přičemž jiné mohou být opomenuty či diskutovány povrchněji. $Z$ toho důvodu jsme se rozhodli triangulovat data získaná z obsahových analýz záznamů z ohniskových skupin s daty získanými dotazníkovým šetřením. I zde jsme si vědomi limitů, které s sebou přináší využití dotazníkového šetření. Jedná se jednak o upozornění, která o dotazníku předkládá sám Fantini: „Přestože je tento dotazník svým obsahem působivý, ICC je více než pouhé naplnění jejích jednotlivých indikátorů. [...] Speciálně jedná-li se o povědomí a postoje oproti tradičnějším oblastem dovedností a znalostí" (2001, s. 4). Fantini proto doporučuje zahrnout do hodnocení ICC více rozdílných přístupů k hodnocení (2001, s. 4). Dále pak je nutné vzít v potaz nebezpečí, která s sebou přináší formát dotazníku. Jedná se zejména o možnost sebestylizace respondentů. Toto podporuje např. Denscombe (2003, s. 161), který upozorňuje na nemožnost ověřit pravdivost výpovědí. Obdobně se ohledně nemožnosti ověřit serióznost a upř́mnost odpovědí vyjadřuje např. Gillham (2002, s. 13). Gillham však rovněž vnímá přirozenost stylizace odpovědí respondenty, nevidí za ní nezbytně jejich špatnou vůli, jelikož „zaznamenávání osobních informací na papír je jako pouštět kus sám sebe neznámo kam“ (2002, s. 84).

\section{Výsledky obsahových analýz záznamů z ohniskových skupin}

Při analýze pojetí ICC studenty v počátku i závěru semestru jsme kladli důraz na kvalitativní interpretace pojetí ICC, tj. komplexitu a hloubku porozumění jednotlivým dimenzím. Výstupy obsahových analýz ${ }^{17}$ záznamů ohnisko-

17 Při obsahové analýze dat dle kategoriálního systému byla analyzována shoda s druhým nezávislým kódovatelem (intercoder agreement) s cílem získat reliabilní data. 
vých skupin naznačují, že k rozvoji ICC a jejích dimenzí u studentů daného studijního předmětu došlo. Posun jsme zaznamenali v rámci všech dimenzí ICC, avšak v různé kvalitě. S ohledem na omezený prostor uvedeme reprezentativní výroky pro nejvýznamněji ovlivněné dimenze, tj. dimenze postojů a znalostí, které byly na konci semestru $(\mathrm{K})$ oproti jeho začátku (Z) vnímány komplexněji, s hlubším porozuměním jejím jednotlivým aspektům.

Dimenze postojů: Z: „Hlavně asi postoje. Musím být otevřená a tolerantní vůči jiným kulturám a myslím, že s tímhle postojem můžu respektovat a naučit se respektovat ostatní kultury a entusiasmus, myslím, že entusiasmus ohledně nového je základní." $\rightarrow$ K: „Myslím, že je to o respektu. Musíme nějaký respekt projevit, abychom sami mohli být respektováni. Měli bychom naslouchat dalším lidem a sdílet. Když se něco děje, měli bychom to prostě přejít, být flexibilní. Jsem si vědomá nebezpečí stereotypů a předsudků." Analýza výroků odhalila posun v komplexitě chápání postojové dimenze, tj. uvědomění si charakteristik a kvalit jako např. tolerance, respekt, otevřenost k novému i cizím kulturám, uvědomění si předsudků a stereotypů, potažmo schopnost nezobecňovat, trpělivost, flexibilitu a snahu/touhu učit se.

Dimenze znalostí: Z: „Je důležité vědět odkud pocházejí. No, znát jejich historii a třeba vlajku a jména států a tak." $\rightarrow \mathrm{K}$ : „Potřebujeme znát kulturu, potřebujeme znát jejich tradice a zvyky, potřebujeme také znát něco o nich, o kultuře. Myslím si, že je moje znalost hlubší." Je zřejmé, že v počátku semestru bylo nejvíce zastoupeno tradiční pojetí znalostní dimenze jako reálií cílové kultury (spadající do tzv. Kultury s velkým K), v prủběhu semestru pak došlo k značnému posunu ke komplexnějšímu vnímání znalostí o kultuře (kultura s malým $\mathrm{k}^{18}$ ).

Dimenze povědomí byla konkrétním studijním předmětem rovněž ovlivněna významně, a to zejména $v$ rámci její vnitřní struktury (např. posun od povědomí ostatních k povědomí sebe sama).

Dimenze dovedností a cizojazyčná komunikační kompetence pak byly vyjádřeny méně komplexně, avšak více cíleně, což dokládá napřs. užívání odborného pojmosloví studenty.

Celkově pak došlo k rozvoji porozumění konstruktu ICC a navíc i k porozumění role ICC v rámci procesů učení se a vyučování cizím jazykům. Výroky reprezentující jednotlivé dimenze jsou v závěru studijního předmětu delší

18 Vymezení Kultury s velkým K (big C Culture) a kultury s malým $k$ (small c culture) přijímáme tak, jak jej prezentují originální zdroje americké a anglické provenience (např. Bennet, 1998; Ommagio Hadley, 2001) 
a ve většině případů precizněji formulované. Studenti se v průběhu závěrečné ohniskové skupiny vzájemně méně přerušovali, nedoplňovali se, naopak prezentovali ucelené výroky a vzájemně na sebe reagovali. Lze tedy usuzovat na hlubší porozumění konstruktu ICC, který postihovali komplexněji, a to jak $\mathrm{v}$ rovině horizontální, tak vertikální, tj. v šírí i hloubce jeho pojetí.

\section{Výsledky dotazníkového šetření YOGA Form}

Odpovědi na výzkumné otázky jsme hledali rovněž formou kvantifikace dat získaných z dotazníkového šetření YOGA Form. Zaměřili jsme se na posun studentů $\mathrm{v}$ rámci jednotlivých dimenzí ICC a následnou statistickou analýzu, která sloužila k zodpovězení otázek o statistické významnosti případného rozvoje jednotlivých dimenzí ICC. Statistická analýza nám umožnila nahlédnout rovněž vzájemné vztahy získaných dat. V neposlední řadě jsme ověřili reliabilitu jednotlivých baterií položek v dotazníku (vše viz tabulka 1).

Z dostupných technik deskriptivní statistiky byly využity výpočty míry centrální tendence, tj. aritmetický průměr (tabulka 1 ). $\mathrm{K}$ zodpovězení našich výzkumných otázek - zda u studentů učitelství anglického jazyka $\mathrm{v}$ průběhu studijního předmětu zaměřeného na rozvoj ICC došlo k rozvoji jejích jednotlivých dimenzí, pokud ano, kterých a v jaké míře - jsme tedy z daných položek dotazníku YOGA Form tvořených Likertovou škálou 0 až 5 (viz výše) vypočetli indexy pro jednotlivé dimenze v začátku (Z) a konci (K) semestru. Změna hodnot indexů naznačuje, že v rámci všech dimenzí ICC došlo k posunu, tj. nárůstu. Posuny v rámci jednotlivých dimenzí se však lišily; je tedy nutné se ptát, zda výsledky v jednotlivých dimenzích byly nebo nebyly statisticky významné. $K$ zodpovězení této otázky, tj. $\mathrm{k}$ hledání vzájemných vztahů mezi proměnnými, bylo nutno použít vybranou techniku induktivní statistiky. Z technik bivariační rozdílové statistiky, jejímž předmětem bývá vztah mezi dvěma proměnnými, jsme zvolili t-test pro opakovaná měření, tj. párový t-test; v našem případě se jednalo o měření jednotlivých dimenzí ICC skupiny studentů na začátku $(\mathrm{Z})$ a konci $(\mathrm{K})$ konkrétního studijního předmětu. $\mathrm{V}$ dimenzích znalostí a dovedností byly vypočítány hodnoty $p<0,01$ (zvýrazněno $\mathrm{v}$ tabulce 1 ), proto můžeme prohlásit, že $\mathrm{v}$ rámci dimenzí znalostí $(p=0,001)$ a dovedností $(p=0,006)$ došlo ke statisticky signifikantnímu rozvoji, a to na $99 \%$ hladině významnosti. Dimenze postojů $(p=0,07)$ a povědomí $(p=0,08)$ nesplňují podmínku $p<0,01$, ani $p<0,05$, nelze je tedy označit za dimenze, ve kterých by došlo k statisticky významnému rozvoji, přestože $\mathrm{k}$ jistému posunu v rámci těchto dimenzí došlo. Předložené výsledky reflektují teoretická východiska o snadnějším a rychlejším rozvoji 
zmiňovaných dimenzí oproti dimenzím postojů a povědomí, které vyžadují větší a dlouhodobější pozornost (napřs. Fantini, 2000).

V neposlední řadě byla ověřována vnitřní konzistence jednotlivých baterií položek v dotazníku YOGA Form pomocí výpočtu Cronbachova koeficientu alfa. Z tabulky 1 je zřejmé, že reliabilita všech baterií položek (zvýrazněno v tabulce 1) odpovídala požadovaným hodnotám.

Tabulka 1

Výsledky statistické analýzy dat - YOGA Form

\begin{tabular}{|c|c|c|c|c|c|c|c|c|}
\hline Dimenze ICC & \multicolumn{2}{|c|}{$\begin{array}{l}\text { Znalosti } \\
\text { Z-K }\end{array}$} & \multicolumn{2}{|c|}{$\begin{array}{l}\text { Postoje } \\
\mathrm{Z}-\mathrm{K}\end{array}$} & \multicolumn{2}{|c|}{$\begin{array}{l}\text { Dovednosti } \\
\text { Z-K }\end{array}$} & \multicolumn{2}{|c|}{$\begin{array}{l}\text { Povědomí } \\
\text { Z-K }\end{array}$} \\
\hline Počet položek & \multicolumn{2}{|c|}{11} & \multicolumn{2}{|c|}{13} & \multicolumn{2}{|c|}{11} & \multicolumn{2}{|c|}{18} \\
\hline Indexy (aritm. průměry) & 2,78 & 3,22 & 3,88 & 4,10 & 3,20 & 3,79 & 3,63 & 3,82 \\
\hline $\begin{array}{l}\text { Dosažená hladina párového } \\
\text { t-testu (hodnota } p \text { ) } \\
\text { (hodnota } t \text { ) }\end{array}$ & \multicolumn{2}{|c|}{$\begin{array}{c}0,001 \\
(3,907)\end{array}$} & \multicolumn{2}{|c|}{$\begin{array}{c}0,07 \\
(1,934)\end{array}$} & \multicolumn{2}{|c|}{$\begin{array}{c}0,006 \\
(3,134)\end{array}$} & \multicolumn{2}{|c|}{$\begin{array}{c}0,08 \\
(1,831)\end{array}$} \\
\hline $\begin{array}{l}\text { Reliabilita baterií položek } \\
\text { (Cronbachova alfa) }\end{array}$ & 0,864 & 0,861 & 0,917 & 0,880 & 0,833 & 0,933 & 0,953 & 0,947 \\
\hline
\end{tabular}

Výsledky statistické analýzy tedy přinesly nad očekávání jednoznačné výstupy, a to jak v oblasti kvality výzkumného nástroje (reliabilita), tak v oblasti dosaženého rozvoje dimenzí ICC u studentů (zejména dimenze znalostní a dovednostní).

Souhrnné výsledky výzkumu rozvoje ICC

$\mathrm{Z}$ uvedených výsledků je zřejmé, že u studentů došlo k rozvoji ICC. Naším cílem bylo hodnotit rozvoj jednotlivých dimenzí ICC, nesnažili jsme se tedy identifikovat nejvíce či nejméně rozvinuté dimenze. Prostřednictvím shrnutí a syntézy výsledkủ obou fází výzkumu jsme se pokusili odhalit nejprve rovinu horizontální, tj. šíri zastoupení jednotlivých dimenzí ICC v počátku i závěru semestru, a následně rovinu vertikální, tj. míru rozvoje studentů v jednotlivých dimenzích, a to opětv počátku i závěru semestru. Případný rozvoj jednotlivých dimenzí ICC u studentů jsme pojednali s oporou o teoretická východiska čtyř dimenzí1 ${ }^{19}$ : povědomí, postojové, znalostní a dovednostní. Výsledky výzkumu

19 Dimenze cizojazyčné komunikační kompetence není do prezentace výsledků empirického šetření zahrnuta, jelikož její rozvoj nebyl primárním cílem konkrétního studijního předmětu. 
potvrdily, že u studentů došlo k signifikantnímu rozvoji dimenzí znalostní a dovednostní. $\mathrm{V}$ rámci dimenze povědomí a postojové pak došlo $\mathrm{k}$ iniciaci rozvojových tendencí, což s ohledem na obtížnost jejich didaktizace vnímáme rovněž kladně. Rozvoj studentů $\mathrm{v}$ dimenzích povědomí a postojů navíc předpokládá podmínku dlouhodobého působení na tyto dimenze, přičemž podpora rozvoje reflektivního potenciálu studentů ve vztahu k rozvoji ICC (i iniciaci toho rozvoje) hraje důležitou roli. Rozvoj jednotlivých dimenzí ICC byl v souladu s cíli konkrétního studijního předmětu stanovenými na základě analýzy potřeb studentů v počátku semestru, např. rozvoj povědomí sebe sama a vlastní kultury v rámci dimenze povědomí, propojení dimenze dovednostní se schopností úspěšné interakce např́íč kulturami. Tento výsledek hodnotíme jako pozitivní, jelikož lze na jeho základě vyvozovat, že je rozvoj všech dimenzí ICC studentů v podmínkách formálního vzdělávání možný.

S ohledem na výsledky výzkumného šetření jsme přesvědčeni, že provedený výzkum naplňoval i základní etický požadavek, tj. že byl vedle přínosů v oblasti teoretické a empirické zároveň přínosem i pro jeho účastníky, pro studenty učitelství anglického jazyka.

\section{Diskuse závěrem}

Výstupy realizované studie navozují nové podněty k zamyšlení a diskusi. Vybrané otázky lze stručně formulovat následovně: (a) Jaká je role učitele, který je jako nerodilý mluvčí produktem a nositelem odlišné kultury než kultury cílového jazyka? (b) Je dostatečně reflektována potřeba zařazení rozvoje ICC do přípravného vzdělávání učitelů? (c) Je rozvoj všech dimenzí ICC v realitě formálního vzdělávání možný? (d) Pokud je rozvoj všech dimenzí ICC možný, lze jej následně objektivně hodnotit? (e) Pokud je hodnocení všech dimenzí ICC možné, lze označit výsledky tohoto hodnocení za spolehlivé? Zde se jedná zejména o nepozorovatelné dimenze postojů a povědomí - hovoří lidé ohledně kontroverzních témat pravdu? Je to, co lidé ř́kají, dostatečný ukazatel toho, jak budou jednat? (f) Je výzkum v oblasti rozvoje a hodnocení ICC etický?

Pro náš specifický kontext, a to rozvoj ICC v rámci přípravného vzdělávání učitelů, vnímáme jako zásadní zejména otázku schopnosti studentů, budoucích učitelů anglického jazyka, didakticky transformovat obsah všech dimenzí ICC, a to v ontodidaktické i psychodidaktické rovině. Přestože tedy 
výsledky výzkumného šetření prokázaly rozvoj ICC u studentů, přetrvává zde stěžejní otázka, a to zda budou konkrétní učitelé schopni konstrukt ICC didakticky uchopit ve své pedagogické praxi. Být interkulturně kompetentním jedincem není dostačující kvalitou ke schopnosti rozvíjet ICC v realitě školní třídy. Nutnou podmínkou je Shulmanova didaktická znalost obsahu (1987), tj. připravenost učitelů nabízet žákům obsah tak, aby je vyzýval k jejich vlastnímu zkoumání možností a k ověřování jeho správnosti v komunikaci nebo na základě experimentace zaměřené na určitý fenomén (Slavík \& Janík, 2007, s. 272-273). Jako žádoucí tedy vnímáme následnou přípravu budoucích učitelů v oblasti didaktizace konstruktu ICC.

Nutné je zde propojit rovněž formování/vytváření kognice s její transmisí a zprostředkováním $\mathrm{v}$ rámci didaktické komunikace. Aby žáci dosáhli jisté úrovně rozvoje ICC (nebo alespoň započali tento vývojový proces), je nutné, aby učitelé naplňovali požadavky komunikačního přístupu k výuce (např. Brockmeyerová-Fenclová, Čapek, \& Kotásek, 2000; Janík \& Slavík, 2007; Píšová, 2011). V souladu s tímto přístupem by měli učitelé komunikovat obsah předmětu žákům, v kontextu vyučování cizího jazyka je tento požadavek dále umocněn potřebou „komunikovat komunikaci“, což lze s nadsázkou označit za „komunikaci na druhou“.

\section{Poděkování}

Ráda bych na tomto místě poděkovala doc. PhDr. Michaele Píšové, M.A., Ph.D. za cenné kritické připomínky, které mi věnovala $\mathrm{v}$ průběhu plánování i realizace výzkumu.

\section{Literatura}

Abram, I. (2001). The ABCD of intercultural classroom education. Dostupné z: http://www. tickleproject.eu/toolbox/material/materials_netherlands/Link_7_THE\%20ABCD_ \%200F_\%20INTERCULTURAL_\%20CLASSROOM_\%20EDUCATION.pdf

ABCD Crown model. Pracovní materiál, dosud nepublikováno (osobní kontakty).

Bachman, L. F. (1990). Fundamental considerations in language testing. Oxford: Oxford University Press.

Brockmeyerová-Fenclová, J., Čapek, V., \& Kotásek, J. (2000). Oborové didaktiky jako samostatné vědní disciplíny. Pedagogika, 46(1), 23-37.

Byram, M. (1997). Teaching and assessing intercultural communicative competence. Clevedon: Multilingual Matters.

Byram, M., \& Fleming, M. (1998). Language learning in intercultural perspective, approaches through drama and ethnography. Cambridge: Cambridge University Press. 
Byram, M., Nichols, A., \& Stevens, D. (2001). Developing intercultural competence in practice. Clevedon: Multilingual Matters.

Canale, M., \& Swain, M. (1980). Theoretical bases of communicative approaches to second language teaching and testing. Applied Linguistics, 1(1), 1-47.

Common European framework of reference for languages: Learning, teaching, assessment. (2001). Cambridge: Cambridge University Press.

Day, C. (2011). The new lives of teachers: Reserch which influences. Orbis Scholae, 5(2), 7-29.

Deardorff, D. K. (2004). Intercultural competence model. Identification and assessment of intercultural competence as a student outcome of internationalization. Raleigh NC: North Carolina State University. Dostupné z: http://www.unr.edu/oiss/toolbox/2009/INTERCUL TURAL\%20COMPETENCE\%20MODELS\%20deardorff\%2006.pdf

Deardorff, D. K. (2006). Models of intercultural competence. Dostupné z http://www. bertelsmannstiftung.de/bst/de/media/xcms_bst_dms_30238_30239_2.pdf

Deardorff, D. K. (2009). Implementing intercultural competence assessment. In D. K. Deardorff (Ed.), The SAGE Handbook of intercultural competence (s. 2-52). Thousand Oaks: Sage Publications.

Denscombe, M. (2003). The good research guide. Glasgow: Bell \& Brain.

Faltýn, J. (2005). Teoretická východiska multikulturní andragogiky. Praha: MJF Praha.

Fantini, A. E. (2000). A central concern: Developing intercultural competence. Adapted from a Report by the intercultural communicative competence. Brattleboro: World Learning. Dostupné $\mathrm{z}$ http://www.sit.edu/publications/docs/competence.pdf

Fantini, A. E. (2001). Exploring intercultural competence: A construct propsal. Předneseno na: NCOLCTL Fourth Annual Coneference. Barttleboro, Vermont, USA.

Fantini, A. E. (2005). Assessing intercultural competence: a research project of the federation EIL. Dostupné $\mathrm{z}$ http://www.experiment.org/documents/AppendixG

Fantini, A. E. (2009) Assessing intercultural competence: Issues and tools. In D. K. Deardorff (Ed.), The SAGE Handbook of intercultural competence (s. 456-476). Thousand Oaks: Sage Publications.

Gavora, P. (2010). Úvod do pedagogického výzkumu. Brno: Paido.

Gillham, B. (2002). Developing a questionnaire. London: Continuum.

Hladík, J. (2010). Konstrukce a modely multikulturních kompetencí. Pedagogická orientace, 20(4), 27-47.

Hrdlička, M. (2005). K otázce komunikační metody a komunikativnosti. Příspěvek přednesený v berlínském Českém centru na fóru Komunikativní metody a čeština.

Hymes, D. (1972). On communicative competence. In J. B. Pride \& J. Holme (Eds.), Sociolinguistics (s. 269-293). Harmondsworth: Penguin Books.

Janebová, E., \& Kasíková, H. (2007). Interkulturní výchova. In A. Vališová \& H. Kasíková, et al., Pedagogika pro učitele (s. 291-298). Praha: Grada.

Janík, T., \& Slavík, J. (2007). Vztah obor - vyučovací předmět jako metodologický problém. Orbis Scholae, 2(1), 54-66.

Janoušek, J. (2007). Verbální komunikace a lidská psychika. Praha: Grada.

Ježková, V. (2003). Proměny a inovace ve výuce cizím jazykům v Evropě. In 11. konference ČAPVSociální a kulturní souvislosti výchovy [CD-ROM]. Brno: Paido. 
Klieme, E., Maag-Merki, K., \& Hartig, J. (2010). Pojem kompetence a význam kompetencí ve vzdělávání. Pedagogická orientace, 20(1), 104-119.

Kostková, K. (2010). Teacher and intercultural communicative competence as a challenge. In T. Janík \& P. Knecht (Eds.), New pathways in the professional development of teachers (s. 232-240). Münster: LIT Verlag.

Kostková, K. (2012a). Interkulturní komunikační kompetence $\mathrm{v}$ českých kurikulárních dokumentech. In P. Knápek (Ed.), Interkulturní soužití v kontextu vyučování, kultury a literatury. Pardubice: Univerzita Pardubice.

Kostková, K. (2012b). Rozvoj interkulturní komunikační kompetence. Brno: Munipress.

Kotá, J. (2000). Místo člověka v globalizovaném světě. Pedagogika, 50(1), 1-2.

Leeman, Y., \& Ledoux, G. (2005). Teachers on intercultural education. Teachers and teaching: Theory and practice, 11(6), 575-589.

Lustig, M. W., \& Koestner, J. (2006). Intercultural competence. New York: Pearson Education.

Mareš, J., \& Gavora, P. (1999). Anglicko-český pedagogický slovník. Praha: Portál.

Omaggio Hadley, A. (2001). Teaching language in context. USA: Thomson Heinle.

Píšová, M. (2011). Didaktika cizích jazyků: otázky identity. Pedagogická orientace, 21(2), $145-155$.

Průcha, J. (2001). Multikulturní výchova. Teorie - praxe - výzkum. Praha: ISV Praha.

Průcha, J. (2010). Interkulturní komunikace. Praha: Grada.

Richards, J. C., \& Rodgers, T. S. (2001). Approaches and methods in language teaching. Cambridge: Cambridge University Press.

Shulman, L. B. (1987). Knowledge and teaching: Foundations of the new reform. Harvard Educational Review, 57(1), 1-22.

Společný evropský referenční rámec pro jazyky: Jak se učíme jazykům, jak je vyučujeme a jak v jazycích hodnotíme. (2002). Olomouc: Univerzita Palackého v Olomouci.

Spitzberg, B. H., \& Changnon, G. (2009). Conceptualizing intercultural competence. In D. K. Deardorff (Ed.), The SAGE handbook of intercultural competence (s. 2-52). Thousand Oaks: Sage Publications.

Šebestová, S. (2011). Příležitosti $k$ rozvíjení řečových dovedností ve výuce anglického jazyka: videostudie. Brno: Masarykova univerzita.

Ting-Toomey, S., \& Kurogi, A. (1998). Facework competence in intercultural conflict: an updated face-negotiation theory. International Journal of Intercultural Relations, 22(2), 187-225.

Tomalin, B., \& Stempleski, S. (1993). Cultural awareness. Oxford: Oxford University Press.

Usó-Juan, E., \& Martínez-Flor, A. (2006). Current trends in the development and teaching of the four language skills. Berlin: Mouton de Gruyter.

Varianty projekt, Člověk v tísni, společnost při ČT, o.p.s. (2002). Dostupné z http://www.varianty. cz/cdrom/podkapitoly/a02ikv.pdf

Zerzová, J. (2012). Interkulturní komunikační kompetence a její rozvíjení v hodinách anglického jazyka na 2. stupni základní školy. Brno: Munipress. 


\title{
Autorka
}

Mgr. Klára Kostková, Ph.D., Univerzita Karlova, Pedagogická fakulta, Katedra anglického jazyka a literatury, Celetná 13, 11000 Praha 1,

e-mail: klara.kostkova@pedf.cuni.cz

\section{Intercultural Communicative Competence development in ELT students ${ }^{20}$}

\begin{abstract}
The aim of the paper is to introduce a research study focused on assessment of intercultural communicative competence (ICC) development in student teachers of English language for elementary schools within a study subject Intercultural Communicative Competence. The phenomenon of interculturality poses new demands not only on pedagogical practice, but on research too. In the subsequent part of the study focus lies on intercultural education, the key aim of which is defined as development of ICC. The basis for the further empirical part is to conceptualize the construct of ICC and to elaborate on its consequent didactic aspects, i.e. its development and assessment. In the empirical study we used quantitative as well as qualitative approach to data collection and analysis; data collection techniques used were a YOGA Form questionnaire and focus groups, their records were analyzed by means of content analysis. Research sample consisted of 17 student teachers of English language (15 women and 2 men; average age: 24 years). The research aim was to investigate whether the students' ICC developed during the study subject Intercultural Communicative Competence and if yes, then in which dimensions and to what extent. The research outcomes showed development of all ICC dimensions in the students, however, to different extent. Significant development was reached in the dimensions of knowledge and skills. Development within the dimensions of awareness and attitudes was also detected, however, not on a statistically significant level, yet we view even such initiation of the developmental processes as positive, especially since supporting the reflective potential of students in connection to ICC (and its initiation) also plays its crucial role. In conclusion, implications for pedagogical theory and practice are discussed on the basis of the gained research outcomes, i.e. development mainly in the dimensions of knowledge and skills.
\end{abstract}

Keywords: intercultural communicative competence (ICC), intercultural communicative competence development, intercultural communicative competence assessment, YOGA Form questionnaire

20 ELT - English Language Teacher/Teaching. 